Int. J. Odontostomat.,

4(2):157-160, 2010.

\title{
Primary Herpetic Gingivostomatitis in an Adult Patient Using an Orthodontic Appliance
}

\author{
Gingivoestomatitis Herpética Primaria en un Paciente \\ Adulto Utilizando un Aparato Ortodóntico
}

Matheus Melo Pithon* \& Ana Carolina Dias Viana de Andrade ${ }^{* *}$

PITHON, M. M. \& ANDRADE, A. C. D. V. Primary herpetic gingivostomatitis in an adult patient using an orthodontic appliance. Int. J. Odontostomat., 4(2):157-160, 2010.

ABSTRACT: The present article describes a clinical case of an adult patient using an orthodontic appliance, who returned to the dental office after the placement of orthodontic mini-implants, complaining of aphthas. By means of clinical and case history evaluation the diagnosis of primary herpetic gingivostomatitis was reached. The treatment was prescription of an antiviral agent associated with a chlorhexidine-based oral mouthwash. One week after their onset, there was complete regression of the lesions.

KEY WORDS: adult, stomatitis, herpetic/diagnosis, orthodontics.

\section{INTRODUCTION}

Acute (primary) herpetic gingivostomatitis (AHGS) typically affects children, but rarely, this infection also occurs in adults. Because of the limited symptoms, a dentist may be the first health care practitioner consulted (Chauvin \& Ajar, 2002).

It is therefore important for dentists to be able to recognize the condition. The causative agent for AHGS has been identified as the herpes simplex virus (HSV). HSV is a double-stranded DNA virus and is a member of the human herpes virus (HHV) family officially known as Herpetoviridae (Corella Sanchez \& Reyes Diaz, 1988; Dohvoma, 1994; Gandara-Rey et al., 2004). The virus exists in 2 forms, HSV-1 (or HHV1) and HSV-2 (or HHV-2). Most oral, facial and ocular infections result from HSV-1, whereas HSV-2 accounts for most genital and cutaneous lower body herpetic lesions. Orogenital contact may allow either serotype to cause oral or genital lesions. The 2 forms of HSV have a similar structure but differ in antigenicity, although HSV-2 is reputed to be of greater virulence (Chandrasekar, 1999).
The sites most at risk for HSV infection are the skin, eyes, mucous membranes and central nervous system. HSV is short-lived on external surfaces; infection therefore depends on intimate contact with an individual who is shedding live virus through secretions, saliva or skin (Whallett \& Pahor, 1999).

The severity of signs and symptoms may be attributable to the virulence of the specific strain of HSV and the host's immune response. Once HSV penetrates the host's epithelial cells, viral replication occurs. The newly formed HSV come into contact with sensory nerve endings and are transported to the corresponding ganglion (Chandrasekar). In oral labial herpes, the most common site is the trigeminal ganglion. Here the viral DNA enters the ganglion, where it becomes inactive or latent. The incubation period is the period during which viral replication and transport to the sensory ganglion occur. For HSV, this period is variable and can range from a few days to 3 weeks, but in most cases it is approximately 1 week. The severity of the primary infection depends on the degree of viral replication,

\footnotetext{
Auxiliary professor, Southwest Bahia University UESB, Bahia, Brazil; Doctor of Orthodontics at the School of Dentistry, Federal University of Rio de Janeiro - UFRJ, Brazil.

** Doctor in Dermatology Baiana School of Medicine and Public Health, Brazil.
} 
the host's response to the foreign pathogen and the speed with which latency is established. Asymptomatic primary infections are thought to occur in cases in which HSV causes minimal epithelial cell destruction through replication. In these cases, the newly formed virions enter the sensory axons and become latent in the ganglion. These cases of HSV will have minimal to no manifestations. However, if these virions infect adjacent epithelial cells and continue to cause cell lysis, in conjunction with the inflammatory response mediated by the host immune system, the primary infection is clinically evident and symptomatic (Stanberry et al., 2000).

The objective of the present article is to describe a rare clinical case of an adult patient using an orthodontic appliance, who developed a condition of acute (primary) herpetic gingivostomatitis.
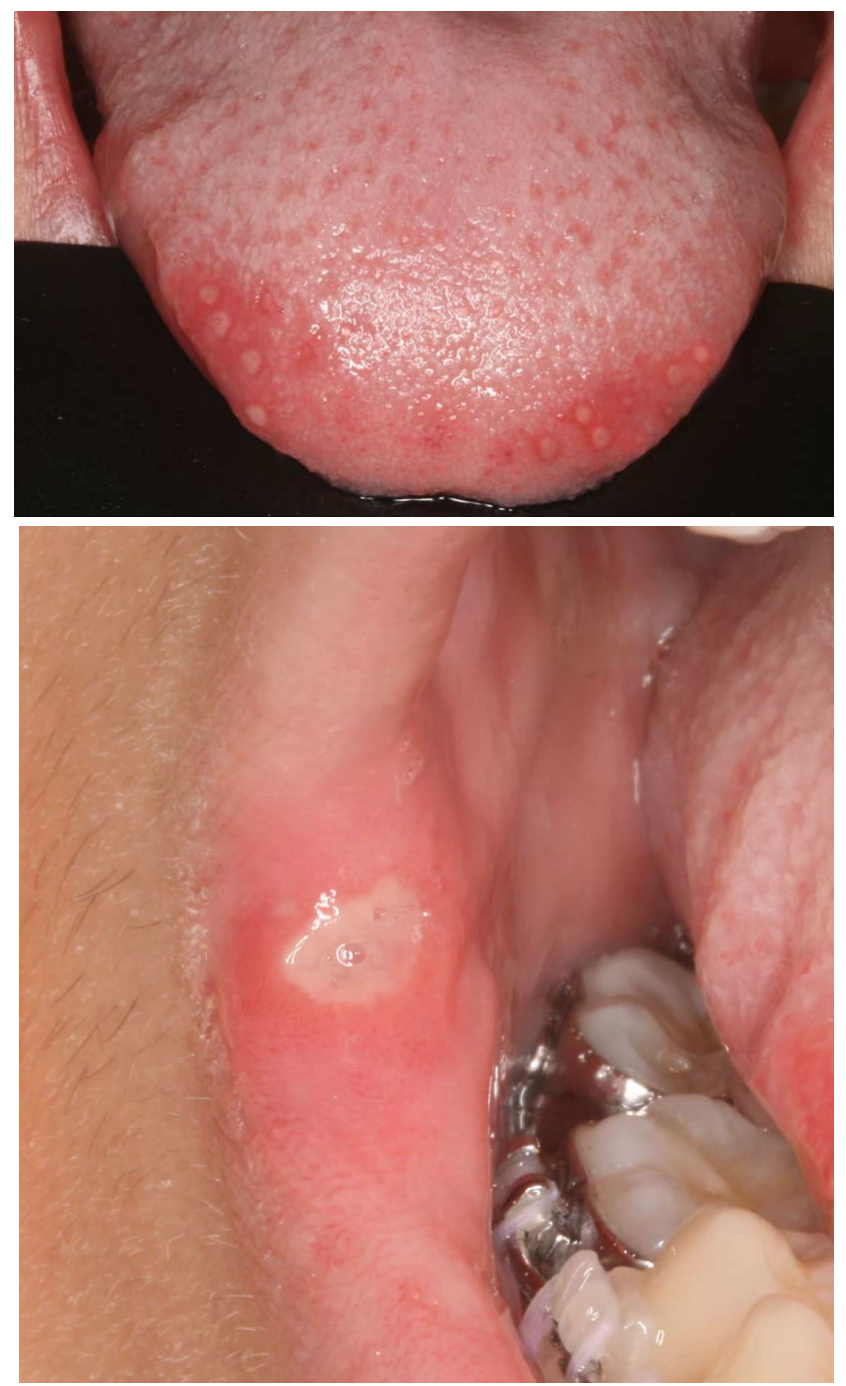

Fig. 1a. Lesions on the lateral edges of the tongue; 1b. Lesion on the labial commissure.

\section{CASE REPORT}

The patient A. B. G., a 23-year-old woman, under orthodontic treatment for the correction of Class II right sub-division malocclusion returned to the dental office two days after her consultation, during which orthodontic mini-implants had been placed, complaining of "aphthas on the tongue". According to the patient, the lesions appeared one day after the mini-implants were placed. She said the lesions began as vesicles that rapidly burst.

The patient also reported rhinorrhea, increase in body temperature and feeling ill. Clinically the lesions presented as multiple erosions on the lateral edges of the tongue and ulceration on the right labial commissure. According to the patient, no such episode had ever occurred before.

From the clinical evaluation and the data informed by the patient, the diagnosis of primary herpetic gingivostomatitis was reached. The patient was prescribed oral acyclovir 220mg every 4 hours for 5 days and mouth washing with $0.12 \%$ chlorhexidine digluconate solution to prevent secondary infection. A cold and pasty diet was recommended. The patient returned a week later with complete remission of the lesions.

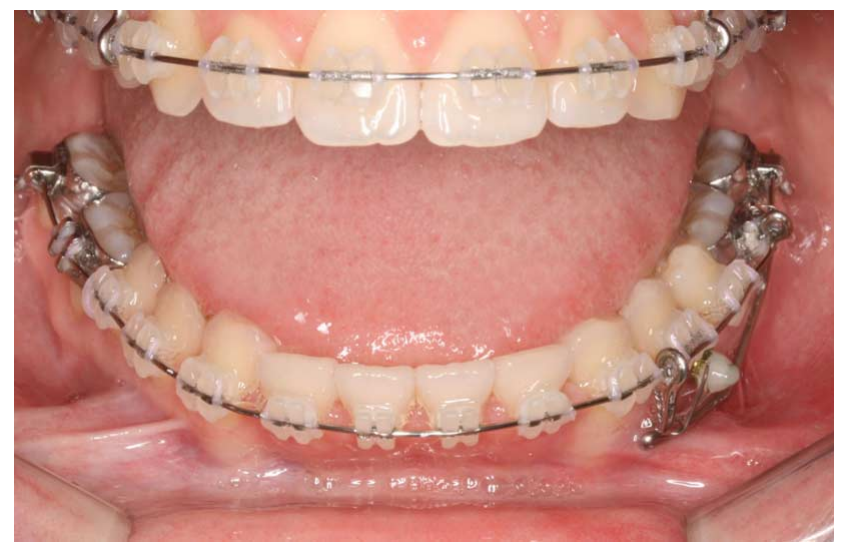

Fig. 2. Oral aspect after one week.

\section{DISCUSSION}

The present article described the clinical case of an adult patient using an orthodontic appliance, who suffered an attack of Primary herpetic gingivostomatitis. The patient had been submitted to placement of orthodontic mini-implants for the distalization of teeth, 
and attributed the appearance of lesions on the edge of the tongue and labial commissure to the placement of the mini-implants.

From the clinical characteristics presented by the lesions, the possibility of these being aphthous lesions was discarded. The differential diagnosis includes infection by other microorganisms, particularly from the coxsackie group; streptococcal pharyngitis; erythema multiform; necrotizing ulcerative gingivitis; and aphthous stomatitis (Regezi \& Sciubba, 2003).

From the clinical aspects and the patient's clinical history, the diagnosis of primary herpetic gingivostomatitis was reached. The diagnosis of primary herpetic gingivostomatitis is generally defined by the clinical data, and no confirmative tests are necessary (Lawall et al., 2005).

Primary acute herpetic gingivostomatitis is the most common pattern of symptomatic primary herpetic infection, and in the majority of cases, it is related to HSV-1 infection. It is more commonly observed in children in the agebracket from 1 to 5 years of age, and rarely in adolescents and young adults (Amir, 2001, 2002), such as the patient described in the present clinical case. According to Ajar \& Chauvin, there is 1 peak of incidence, from 6 months to 5 years. It rarely affects children under the age of six months, who apparently present circulating antibodies transmitted by the mother (King et al., 1992), and adults. The greater occurrence in children may be justified by the wide dissemination of the virus and due to early exposure to it (Meister et al., 1982).

It is worth pointing out that primary infection by HSV-1 can be subclinical or symptomatic (MacPhail \& Greenspan, 1995). Its severity will depend on the degree of viral replication, host's response to the pathogen, and the speed with which latency is established (Ajar \& Chauvin). In the present case no exacerbated lesions were noted, such as those described by Lawall et al. and Gandara-Rey et al. when they reported cases of Primary herpetic gingivostomatitis in adult patients.

The therapeutic procedure in this case was the use of oral acyclovir 220mg every 4 hours for 5 days and mouth washing with $0.12 \%$ chlorhexidine digluconate solution to prevent secondary infection (Lawall et al.). There was regression of the lesion after one week.

The dentist (Orthodontist) plays a remarkable role in the diagnosis of primary acute herpetic gingivostomatitis considering that due to the rich symptomatology of oral lesions, he/she is the first professional to be consulted. This being so, it is important for him/her to be capable of recognizing the disease and creating the best conditions for the well being of his/her patient.

Moreover, the acute forms of HSV virus infection are highly transmittable. This potential is of particular interest to dental professionals who are exposed to contact with herpetic lesions on a day to day basis. For this reason, every type of protective apparel (Protective goggles, mask, gloves, cap and overalls) must constantly be used, especially due to the cases of subclinical manifestations that may not be detected. Patients must be instructed with respect to the possibility of transmission of the virus, and also of the need to diminish close contact in the presence of active lesions, in order to prevent the contamination of other areas of the body.

In conclusion, from the case described, the possibility of the occurrence of primary acute herpetic gingivostomatitis in an adult patient becomes evident, and the orthodontist must be alert to the clinical findings, considering that no matter how unlikely a diagnostic hypothesis age may be, it cannot be the only datum taken into consideration for arriving at the final diagnosis.

PITHON, M. M. \& ANDRADE, A. C. D. V. Gingivoestomatitis herpética primaria en un paciente adulto utilizando un aparato ortodóntico. Int. J. Odontostomat., 4(2):157-160, 2010.

RESUMEN: El presente artículo describe un caso clínico de un paciente adulto utilizando un aparato de ortodoncia, que regresó a la consulta dental después de la colocación de mini-implantes ortodónticos, quejándose de aftas. Por medio de la evaluación clínica y de historia del caso, el diagnóstico de gingivoestomatitis herpética primaria fue realizado. El tratamiento fue la prescripción de un agente antiviral asociados con un enjuague bucal con clorhexidina. Una semana después de su inicio, se produjo regresión completa de las lesiones.

PALABRAS CLAVE: adultos, estomatitis, herpética/diagnóstico, ortodoncia. 
PITHON, M. M. \& ANDRADE, A. C. D. V. Primary herpetic gingivostomatitis in an adult patient using an orthodontic appliance. Int. J. Odontostomat., 4(2):157-160, 2010.

\section{REFERENCES}

Amir, J. Clinical aspects and antiviral therapy in primary herpetic gingivostomatitis. Paediatr. Drugs, 3:5937, 2001.

Amir, J. Primary herpetic gingivostomatitis--clinical aspects and anti-viral treatment. Harefuah, 141:814, 124, 2002.

Chandrasekar, P. H. Identification and treatment of herpes lesions. Adv. Wound Care, 12:254-62, 1999.

Chauvin, P. J. \& Ajar, A. H. Acute herpetic gingivostomatitis in adults: a review of 13 cases, including diagnosis and management. J. Can. Dent. Assoc., 68:247-51, 2002.

Corella Sanchez, R. \& Reyes Diaz, J. M. Primary herpetic gingivostomatitis in a group of children. Rev. Cubana Estomatol., 25:55-64, 1988.

Dohvoma, C. N. Primary herpetic gingivostomatitis with multiple herpetic whitlows. Br. Dent. J., 177:251-2, 1994.

Gandara-Rey, J. M.; Pacheco-Martins, J. L.; GandaraVila, P.; Blanco-Carrion, A. \& Garcia-Garcia, A. Primary herpetic gingivostomatitis in a 65-year-old patient. Med. Oral, 7:180-3, 2002.

King, D. L.; Steinhauer, W.; Garcia-Godoy, F. \& Elkins, C. J. Herpetic gingivostomatitis and teething difficulty in infants. Pediatr. Dent., 14:82-5, 1992.

Lawall, M. A.; Almeida, J. F. A.; Bosco, J. M. D. \& Bosco, Á. Primary herpetic gingivostomatitis in adult: case report. Revista Odonto. Ciência, 20:191-4, 2005.

MacPhail, L. \& Greenspan, D. Herpetic gingivostomatitis in a 70-year-old man. Oral Surg. Oral Med. Oral Pathol. Oral Radiol. Endod., 79:502, 1995.

Meister, F. Jr.; Van Swol, R. L. \& Rank, D. F. Clinical variations of acute herpetic gingivostomatitis. Quintessence Int. Dent. Dig., 13:573-9, 1982.

Regezi, J. A. \& Sciubba, J. J. Oral Pathology-Clinical Pathologic Correlations. Philadelphia, Saunders, 2003.
Stanberry, L. R.; Cunningham, A. L.; Mindel, A.; Scott, L. L.; Spruance, S. L.; Aoki, F. Y. \& Lacey, C. J. Prospects for control of herpes simplex virus disease through immunization. Clin. Infect. Dis., 30:549-66, 2000.

Whallett, E. J. \& Pahor, A. L. Herpes and the head and neck: the difficulties in diagnosis. J. Laryngol. Otol., 113:573-7, 1999.

Correspondence to:

Matheus Melo Pithon

Av. Otávio Santos, 395, sala 705

Centro Odontomédico Dr. Altamirando da Costa Lima Vitória da Conquista

CEP: 45020-750

Bahia

BRAZIL

Email: matheuspithon@bol.com.br

Received: 25-06-2010

Accepted: 22-07-2010 